\title{
ISOLASI BAKTERI YANG TERDAPAT PADA KULIT UDANG
}

\author{
Ahmad Thalib \\ Staf Pengajar FAPERTA UMMU-Ternate, e-mail: madoks75@yahoo.co.id
}

\begin{abstract}
ABSTRAK
Kitosan merupakan limbah dari bagian-bagian tubuh udang yang tidak dimanfaatkan dan dibuang pada proses pengolahan yang terdiri dari, kepala, jengger atau genjer, kulit, ekor atau kotoran yang dibuang. kitosan adalah senyawa organik turunan chitin, berasal dari biomaterial chitin yang dewasa ini banyak dimanfaatkan untuk berbagai keperluan, antara lain: pengawet biji-bijian terhadap berbagai hama, membersihkan dan menjernihkan air, sebagai memberan atau kapsul pelindung obat, immobilisasi enzim-sel-bakteri, bahan kosmetik, dan sebagai makanan penjaga kesehatan (bukan obat). Kitosanase diproduksi oleh berbagai macam organisme, seperti actinomycetes, fungi, tumbuhan dan bakteri. Di antara semua organisme penghasil enzim kitosanase, bakteri mendapat perhatian khusus karena peranan bakteri yang cukup penting dalam ekosistem. Penggunaan bakteri telah banyak dilakukan dalam penelitian untuk menjelaskan mekanisme hidrolisis kitosan menjadi oligomernya secara biokimia maupun molekular.
\end{abstract}

\section{Kata Kunci: Bakteri, isolasi, kulit udang}

\section{PENDAHULUAN}

\subsection{Latar belakang}

Kitosan merupakan polisakarida yang diperoleh dari hasil deasetilasi kitin. Unit penyusun kitosan merupakan disakarida (1-4)-2amino-2-deoksi- $\beta$-D-glukosa yang diekstraksi dari eksokeleton seperti udang, rajungan, lobster, tiram dan sebagainya (Gooday, 1994). Namun demikian, bahan baku utama yang digunakan dalam proses pembuatan kitin dan kitosan adalah limbah kulit udang. Pemanfaatan kitosan pada beberapa tahun belakangan mengalami peningkatan yang cukup signifikan, terutama dalam industri farmasi dan makanan (Li et al. 1997).

Seperti halnya kitin yang dapat diubah menjadi lebih sederhana, kitosan dapat dipotong dan potongan kitosan dikenal dengan nama oligomer kitosan atau kitooligosakarida. Produk turunan ini telah banyak diaplikasikan untuk berbagai keperluan seperti abat antitumor, antimikroba, dan antikolesterol. Selain itu, kitooligosakarida juga dipercaya dapat mencegah kerusakan hati akibat penimbunan lemak dan konsumsi alkohol yang berlebihan (Anonim, 2004).

Peranan ologomer kitosan yang cukup besar tersebut merangsang eksplorasi enzim pendegradasi kitosan. Hal ini disebabkan oleh kenyataan masih sedikitnya informasi yang tersedia tentang enzim tersebut, sementara kebutuhan akan enzim pendegradasi kitosan semakin meningkat.

Enzim pendegradasi kitosan dikenal dengan istilah kitonase. Enzim kitonase merupakan enzim yang menghidrolisis kitosan pada ikatan glikosidik kitosan untuk menghasilkan oligomer kitosan (Alasalvar et al. 2000). Penggunaan enzim kitonase unutuk memproduksi oligomer kitosan merupakan salah satu cara yang dipilih karena lebih aman dan bersifat spesifik dibanding penggunaan reaksi kimia.

Kitosanase diproduksi oleh berbagai macam organisme, seperti actinomycetes, fungi, tumbuhan dan bakteri. Di antara semua organisme penghasil enzim kitosanase, bakteri mendapat perhatian khusus karena peranan bakteri yang cukup penting dalam ekosistem. Penggunaan bakteri telah banyak dilakukan dalam penelitian untuk menjelaskan mekanisme hidrolisis kitosan menjadi oligomernya secara biokimia maupun molekular.

Bakteri yang terdapat pada kulit udang merupakan bakteri yang cukup menarik untuk dipelajari, karena keberadaannya pada kulit 
udang yang sering bersifat merugikan. Hal ini terjadi pada limbah kulit udang yang akan digunakan dalam produksi kitin dan kitosan. Limbah kulit udang sebagai sumber kitin dan kitosan, menjadi lebih cepat rusak karena proses degradasi bakteri pembusuk yang terdapat pada kulit udang (Anonim. 1992). Kemampuan degradasi bakteri tersebut dapat dimanfaatkan dalam pembuatan kitosan dan turunannya secara enzimatis.

Salah satu koloni bakteri yang cukup unik untuk dipelajari adalah bakteri yang berasosiasi dengan kulit udang. Koloni bakteri tersebut mampu memanfaatkan jasad renik di lingkungan perairan untuk memproduksi makanan bagi koloninya. Kemampuan bakteri tersebut memperlihatkan adanya kemampuan ekstra pada koloni dalam memproduksi metabolit, termasuk didalamnya dalam pembentukan berbagai enzim penting dalam lingkungan tersebut, termasuk enzim kitosanase. Oleh sebab itu. Untuk mengetahui kemampuan bakteri yang berasosiasi dengan kulit udang dalam memproduksi enzim kitosanase maka perlu dilakukan penelitian.

\subsection{Tujuan}

Tujuan dari penelitian ini adalah untuk mengisolasi bakteri yang terdapat pada kulit udang, menguji sifat kitinolitik bakteri yang terdapat pada kulit udang dan mengetahui nilai aktivitas kitonase dan protein enzim yang dihasilkan oleh bakteri yang terdapat pada kulit udang.

\section{METODOLOGI}

\subsection{Waktu dan Tempat}

Penelitian ini dilakukan selama kurang lebih 4 bulan terhitung sejak tanggal 5 Oktober sampai bulan Desember 2006, dilakukan di Laboratorium Bioteknologi Hasil Perairan dan Laboratorium Mikrobiologi, FPIK-IPB, Bogor.

\subsection{Alat dan Bahan}

Alat-alat yang digunakan dalam penelitain ini terdiri dari pisau, timbangan digital, mortar, erlenmeyer, gelas ukur, cawan petri, tabung reaksi, kertas alumunium, pipet, bulb, mikropipet/tip steril, hotplate, pengaduk magnet, autoklaf, vortex mixer, inkubator goyang, sentrifus, lemari es, oven, $\mathrm{pH}$ meter, termometer, penggaris, kertas saring whatman, glass woll, mikroskop, pinset, tisu, lampu bunsen, laminer, korek api, tabung eppendorf, penangas air goyang, thermoblock, dan spektrofotometer.
Bahan utama pada penelitain ini adalah udang yang di beli di Pasar Anyar Bogor, kemudian di bawa ke Laboratorium dan ditreatmen dan dilakukan analisa selanjutnya (dalam hal ini kulit udang pada kepala) Selain itu, penelitian ini juga menggunakan beberapa bahan pada setiap tahapan kerja. Pada tahap isolasi digunakan media pertumbuhan sea water complete (SWC) dengan komposisi ekstrak khamir, pepton, gliserol dan air laut steril. Tahap ini juga menggunakan pewarna violet kristal dan safranin untuk melihat bentuk dan jenis Gram bakteri. Pada tahap seleksi digunakan dua macam media yaitu minimal syntetic media (MSM) yang mengandung komposisi $\mathrm{KH}_{2} \mathrm{PO}_{4}, \mathrm{NaCl}$, $\left(\mathrm{NH}_{4}\right)_{2} \mathrm{SO}_{4}$, ekstrak khamir dan agar; serta MSM bersubstrat koloidal kitin. Pada tahap pemekatan enzim, bahan yang digunakan adalah amonium sulfat $\left(\left(\mathrm{NH}_{4}\right)_{2} \mathrm{SO}_{4}\right)$. Bahan-bahan lain yang juga digunakan adalah beberapa macam bufer, pewarna Schales untuk analisa enzim dan pewarna Lowry untuk analisa protein, larutan kitosan, alkohol serta akuades.

\subsection{Prosedur Kerja}

Prosedur kerja secara keseluruhan dapat dilihat pada diagram pada Gambar 1 .

\subsection{Isolasi Bakteri Penghasil Kitosanase}

Isolasi bakteri dilakukan untuk mendapatkan koleksi isolat yang berasosiasi dengan spons. Koleksi isolat tersebut kemudian digunakan untuk pengisolasian bakteri kitinolitik dan pengujian enzim kitosanase. Diagram alir proses isolasi ditunjukkan pada diagram pada Gambar 2.

\subsubsection{Pengujian bakteri kitinolitik (modifikasi Kobayashi dan Holtman 1997)}

Pengujian bakteri kitinolitik dilakukan dengan menggunakan metode tusuk. Koloni tunggal yang telah diperoleh dari tahap isolasi diambil dengan menggunakan tusuk gigi steril, kemudian ditusukkan ke dalam media padat minimal syntetic media (MSM) yang mengandung koloidal kitin. Bakteri yang telah ditusukkan ke dalam media kemudian diinkubasi pada suhu $30^{\circ} \mathrm{C}$ selama 5 hari. Aktivitas kitinolitik bakteri dapat dilihat dari pembentukkan zona bening di sekeliling koloni.

Pembentukan zona bening pada media bersubstrat koloidal kitin dapat dijadikan sebagai parameter kualitatif enzim kitinolitik. Parameter ini dilihat melalui penentuan indeks kitinolitik (IK). Penentuan nilai IK (Kusumawati 2003) diukur dengan formula berikut: 
Indeks Kitinolik $=\frac{\text { Diameter zona Bening }(\mathrm{cm})}{\text { Diameter Koloni }}$

Isolat dengan nilai IK besar dianggap memiliki aktivitas yang tinggi. Selanjutnya, tiga isolat dengan nilai IK terbesar diuji lebih lanjut dengan uji kuantitatif.

\subsubsection{Penentuan Waktu Produksi dan Seleksi Isolat Potensial}

Pada tahap ini dilakukan penentuan waktu propagasi dan waktu produksi optimal dari ketiga

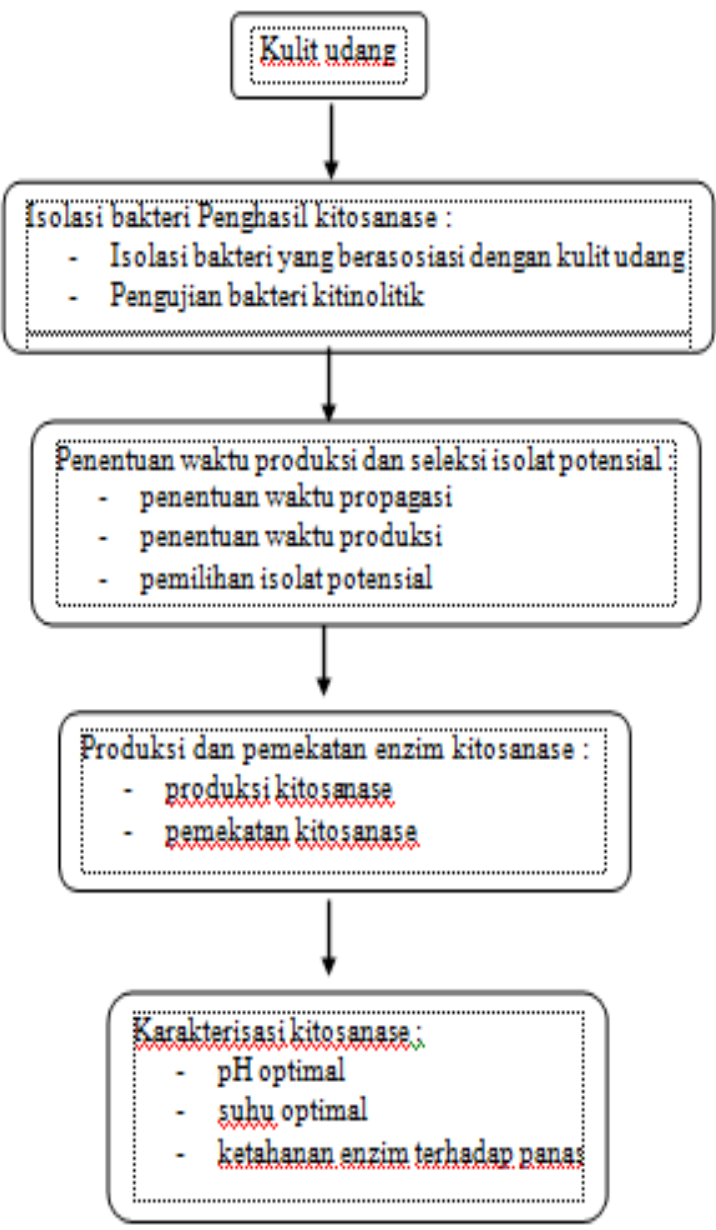

Gambar 1. Diagram Alir Tahapan Penelitian

(a) Penentuan waktu propagasi (Cappuccino dan Sherman 1983)

Waktu propagasi diukur secara spektrofotometris, yaitu dengan mengukur kerapatan sel (optical density) menggunakan spektrofotometer. Kegiatan ini dimulai dengan menumbuhkan isolat dalam erlenmeyer $300 \mathrm{ml}$ yang berisi $200 \mathrm{ml}$ media pertumbuhan MSM cair . Isolat diinkubasi pada penangas air goyang dengan kecepatan agitasi $100 \mathrm{rpm}$ dan suhu $30{ }^{\circ} \mathrm{C}$ isolat dengan nilai IK terbesar yang telah diperoleh dari tahap pertama. Tujuan dari kegiatan ini adalah mengetahui waktu yang tepat untuk memindahkan isolat ke dalam media produksi dan mengetahui waktu optimal produksi enzim dari isolat tersebut. Kegiatan ini juga dilakukan untuk mengetahui pertumbuhan bakteri pada media produksi dan menentukan satu isolat potensial yang akan diproduksi dan diuji lebih lanjut.

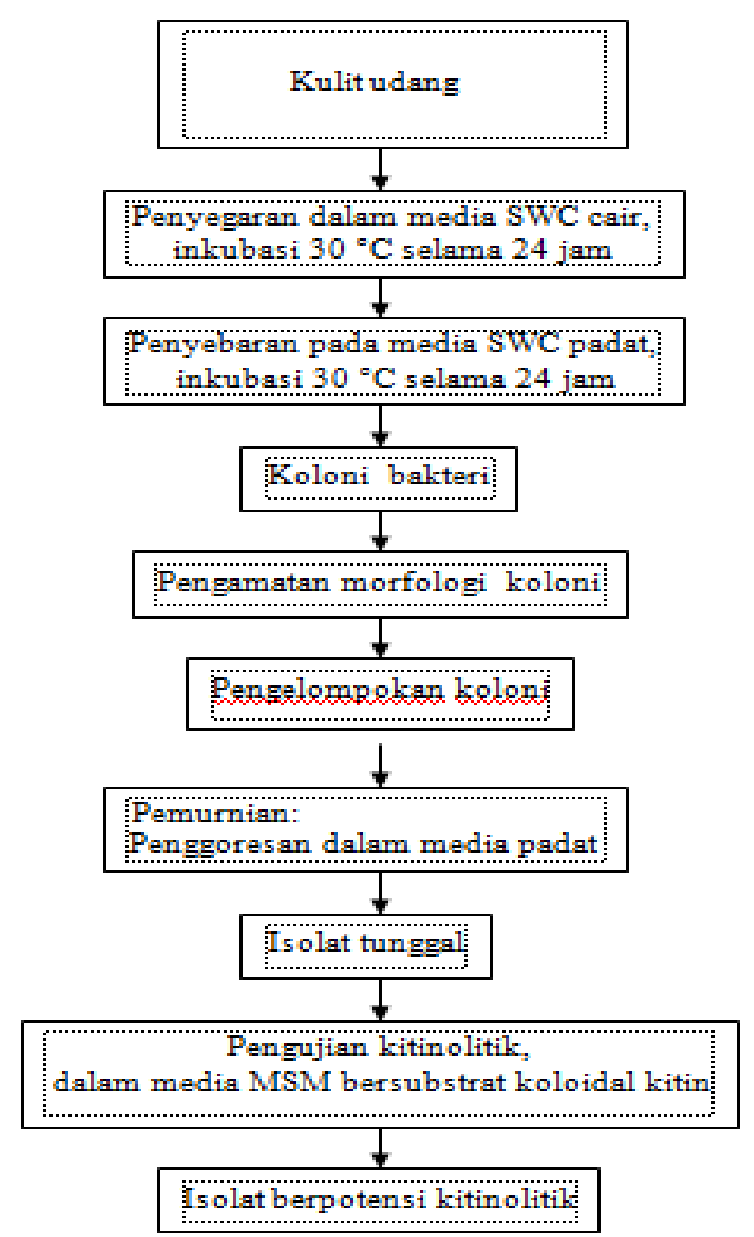

Gambar 2. Diagram alir proses isolasi bakteri kitinolitik

selama waktu tertentu. Pengamatan dilakukan setiap 4 jam dengan mengambil $10 \mathrm{ml}$ sampel dan dipindahkan ke dalam tabung reaksi steril. Sampel tersebut kemudian diukur absorbansinya dengan spektrofotometer pada panjang gelombang $660 \mathrm{~nm}$. Nilai absorbansi yang diperoleh dari pengukuran dengan spektrofotometer tersebut selanjutnya diplotkan untuk memperoleh kurva pertumbuhan. Waktu 
propagasi ditentukan berdasarkan bentuk kurva yang dihasilkan.

(b) Penentuan waktu produksi

Kegiatan ini diawali dengan menumbuhkan isolat pada media yang akan digunakan untuk produksi, yaitu media MSM cair yang mengandung koloidal kitin. Isolat dimasukkan ke dalam media pada waktu propagasi optimalnya dan diinkubasi selama sepuluh hari. Setiap hari dilakukan pengambilan $5 \mathrm{ml}$ sampel kultur untuk pengujian aktivitas kitosanase (Yoon et al. 2000 dalam Chasanah 2004) dan pengukuran nilai protein (metode Lowry). Waktu optimal produksi ditentukan dengan melihat nilai aktivitas kitosanase dan jumlah protein yang dihasilkan oleh kultur bakteri.

\section{(c) Pemilihan isolat potensial}

Isolat potensial ditentukan berdasarkan nilai Indeks Kitinolitik (IK) dan sifat isolat setelah ditumbuhkan dalam media produksi. Berdasarkan nilai aktivitas kitosanase dan jumlah protein yang diperoleh dari tahap sebelumnya maka ditentukan waktu produksi optimal. Isolat potensial dipilih dari isolat yang memiliki IK terbesar, serta waktu propagasi dan waktu produksi yang tercepat. Isolat potensial tersebut digunakan dalam produksi dan pengujian selanjutnya.

\subsubsection{Produksi \\ dan \\ Pemekatan \\ Enzim}

\section{Kitosanase}

Kegiatan ini bertujuan untuk memperoleh enzim kitosanase yang akan digunakan dalam pengujian karakteristik. Tahap ini dimulai dengan memproduksi sejumlah enzim dari isolat terpilih, selanjutnya enzim dipekatkan dengan tujuan pemurnian.

\section{(a) Produksi kitosanase}

Produksi enzim kitosanase dimulai dengan menginokulasi $10 \%$ inokulum isolat terpilih pada $150 \mathrm{ml}$ media produksi, yaitu MSM cair yang diperkaya dengan koloidal kitin $0.5 \%$. Fermentasi dilakukan pada inkubator goyang dengan suhu $30{ }^{\circ} \mathrm{C}$ dan kecepatan agitasi $100 \mathrm{rpm}$ sampai waktu produksi optimalnya, yang diketahui dari tahap sebelumnya. Isolat bakteri yang tumbuh pada media produksi selanjutnya disentrifugasi dengan kecepatan $10.000 \mathrm{rpm}$ selama 15 menit pada suhu $4{ }^{\circ} \mathrm{C}$. Sentrifugasi ini bertujuan untuk memisahkan endapan dan supernatan yang mengandung enzim kasar. Supernatan tersebut digunakan untuk pengujian selanjutnya.

\section{(b) Pemekatan enzim kitosanase (Bollag dan Edelstein 1991) \\ Enzim kasar yang terdapat pada supernatan} dipekatkan dengan menambahkan amonium sulfat $\left(\left(\mathrm{NH}_{4}\right)_{2} \mathrm{SO}_{4}\right)$ dengan konsentrasi $30 \%, 40$ $\%, 50 \%, 60 \%, 70 \%$, dan $80 \%$ kejenuhan untuk menentukan konsentrasi optimal. Proses pengendapan dilakukan dengan cara penambahan $\left(\mathrm{NH}_{4}\right)_{2} \mathrm{SO}_{4}$ ke dalam supernatan sedikit demi sedikit. Selama proses pengendapan, supernatan dihomogenkan dengan menggunakan magnetic stirer, dengan kondisi lingkungan bersuhu rendah. Supernatan yang telah homogen kemudian didiamkan selama 24 jam di dalam refrigerator pada suhu $\pm 4{ }^{\circ} \mathrm{C}$. Supernatan selanjutnya disentrifugasi dengan kecepatan agitasi $10.000 \mathrm{rpm}$ selama 15 menit pada suhu $4{ }^{\circ} \mathrm{C}$. Sentrifugasi bertujuan untuk memisahkan supernatan dengan pelet yang mengandung enzim. Pelet yang telah diperoleh selanjutnya digunakan dalam uji karakterisasi.

\subsubsection{Karakterisasi Enzim Kitosanase}

Enzim dalam pelet yang telah diperoleh dari hasil pengendapan amonium sulfat dilarutkan dalam bufer fosfat $\mathrm{pH} 6$ dengan konsentrasi 0.05 M. Enzim kemudian dikarakterisasi untuk mengetahui $\mathrm{pH}$ dan suhu optimal, kestabilan enzim pada suhu tertentu serta pengaruh logam dan EDTA terhadap aktivitas enzim.

(a) Penentuan $\mathrm{pH}$ dan suhu optimum aktivitas enzim

Penentuan $\mathrm{pH}$ optimum dilakukan dengan mereaksikan enzim pada bufer dengan variasi nilai $\mathrm{pH}$ yang berkisar antara 3 sampai dengan $\mathrm{pH}$ 9. Bufer yang digunakan dalam penentuan $\mathrm{pH}$ optimum adalah bufer sitrat $(\mathrm{pH} 3$ dan 4), bufer sitrat-fosfat ( $\mathrm{pH} \mathrm{4,5,} \mathrm{dan} \mathrm{6),} \mathrm{bufer} \mathrm{fosfat}$ (pH 6, 7, dan 8), bufer borat ( $\mathrm{pH} 8$ dan 9). Penentuan suhu optimum dilakukan dengan mereaksikan enzim pada $\mathrm{pH}$ optimumnya pada berbagai suhu reaksi. Variasi suhu yang dicobakan pada penelitian ini adalah $30{ }^{\circ} \mathrm{C}, 37$ ${ }^{\circ} \mathrm{C}, 50{ }^{\circ} \mathrm{C}, 60{ }^{\circ} \mathrm{C}, 70{ }^{\circ} \mathrm{C}$, dan $80{ }^{\circ} \mathrm{C}$. Hasil reaksi enzim dianalisa nilai aktivitas kitosanase (Yoon et al. 2000, diacu dalam Chasanah 2004) serta jumlah proteinnya (Metode Lowry).

\section{(b) Penentuan ketahanan panas aktivitas enzim}

Tujuan kegiatan ini adalah untuk mengetahui waktu yang diperlukan enzim untuk kehilangan aktivitasnya. Pengujian dilakukan dengan memanaskan enzim pada suhu $37{ }^{\circ} \mathrm{C}$, $60{ }^{\circ} \mathrm{C}$, dan $70{ }^{\circ} \mathrm{C}$ selama waktu tertentu. Setiap 15 menit enzim yang telah dipanaskan tersebut 
diangkat dan direaksikan pada $\mathrm{pH}$ optimal dan suhu inkubasi optimalnya Pada tahap ini dilakukan analisa aktivitas kitosanase (Yoon et al. 2000, diacu dalam Chasanah 2004) dan pengukuran nilai protein (metode Lowry).

1. Isolasi bakteri yang beasosiasi dengan kulit udang

\section{a. Enrichment}

Sampel kulit udang sebanyak 5 gram dimasukkan ke dalam $50 \mathrm{ml}$ media SWC/MB cair. Sampel diinkubasi pada shaker waterbath selama 24 jam pada suhu $30^{\circ} \mathrm{C}$.

\section{b. Penyebaran}

Sampel hasil enrichment kenmudian diambil sebanyak $100 \mu \mathrm{l}(1 \mathrm{ml})$ dan disebar ke atas media SWC padat, kemudian diratakan dengan spatula. Sampel selanjutnya diikubasi pada suhu $30^{\circ} \mathrm{C}$ selama $3 \times 24$ jam sampai koloni bakteri tumbuh pada media tersebut.

\section{c. Pemurnian}

Koloni yang tumbh diamati berdasarkan perbedaan morfologi. Setiap koloni yang berbeda kemudian di gores pada media padat dan diinkubasi pada suhu $30{ }^{\circ} \mathrm{C}$ sampai diperoleh koloni tunggal yang terpisah dari koloni lainnya.

\section{d. Pewarnaan Gram}

Koloni tunggal yang diperoleh dari tahap pemurian kemudian diuji dengan pewarnaan Gram. Caranya adalah dengan mengambil 1 ose biakan bakteri dan di totol pada kaca obyek, kemudian dikeringkan. Selanjutnya teteskan pewarna CV dan diamkan selama 1 menit. Bilas hasil totlan dengan air mengalir. Selanjutnya teteskan lugol ke atas sampel dan diamkan selama 1 menit, kemudian bilas kembali dengan air mengalir. Teteskan alkohol ke atas sampel dan diamkan selama 1 menit, serta bilas kembali dengan air megalir. Langkah terkahir, tetskan safranin ke atas sampel dan diamkan selama 1 menit. Selanjutnya bilas sampel dengan air mengalir, bersihkan sisa air dengan kertas tissue. Sampel kemudian diamati di bawah mikrokop.

\section{Uji Kitinolitik}

Koloni tunggal yang telah diproses dari tahap isolasi diambil menggunakan tusuk gigi steril, kemudian ditusukkan ke dalam media padat Minimal Syntetic Media (MSM) padat bersubstrat koloidal kitin. Bakteri yang telah ditusukkan ke dalam media kemudian diinkubasi pada suhu $30^{\circ} \mathrm{C}$ selama beberapa hari sampai timbul zona bening di sekelilingi koloni.

\section{Penentuan waktu propagasi berdasarkan kurva pertumbuhan \\ Isolat tunggal terpilih diambil sebanyak 1} ose dan dipindahkan ke dalam $200 \mathrm{ml}$ media pertumbuhan MSM cair. Isolat diinkubasi pada shaker waterbath dengan kecepatan 100rpm dan suhu $30^{\circ} \mathrm{C}$ selama waktu tertentu. Pengamatan dilakukan setiap 4 jam dengan dengan mengambil $10 \mathrm{ml}$ sampel dan dipindahkan ke dalam tabung reaksi steril. Sampel kemudian di pindahkan dalam tabung reaksi steril. Sampel kemudian di ukur absobansinya dengan spektrofotometer pada panjang gelombang 660 $\mathrm{nm}$.

\section{Penentuan waktu produksi}

Isolat terpilih dimasukkan ke dalam media MSM cair bersubstrt koloidal kitin pada waktu propagasi optimalnya kemudian diinkubasi selama waktu tertentu. Setiap hari dilakukan pengambilan $10 \mathrm{ml}$ sampel kultur kemudian dilakukan pengukuran absorbansi media, pengujian aktivitas kitinase dan pengukuran nilai protein (Metode Bradford). Waktu optimal produksi ditentukan dengan melihat nilai aktivitas kitonase dan jumlah protein yang dihasilkan oleh kultur bakteri.

\subsection{Pembuatan Koloidal Kitin (Arnold dan Solomon 1986).}

Kitin komersil sebanyak 20 gr dicampur dengan $600 \mathrm{ml}$ HCL pekat (37,8 \%), kemudian disimpan selama semalam pada suhu $4^{0} \mathrm{C}$. Langkah selanjutnya adalah penyaringan dengan menggunakan glass wool di dalam ruang asam. Filtrat yang di dapatkan dari penyaringan di encerkan dengan menggunakan $400 \mathrm{ml}$ aQuades dingin. Filtrat kemudian dinetralkan dengan menggunakan $\mathrm{NaoH} 12 \mathrm{~N}$ sampai mencapai $\mathrm{pH}$ 7. Campuran tersebut disentrifuge dengan kecepatan agitasi sebesar $7000 \mathrm{rpm}$ selama 15 menit pada suhu $4^{0} \mathrm{C}$ untuk memisahkan supernatan dan endapan. Supernatan yang diperoleh kemudian dibuang, sedangkan endapan yang terbentuk dicuci dengan menambahkan aQuades dingin.Pencucian ini dilakukan sebanyak 2 kali dengan tujuan adalah untuk menghilangkan garam yang terbentuk selama proses penambahan asam dan basa. Langkah selanjutnya adalah mensentrifuge kembali larutan pencucian terakhir dengan kecepatan agitasi 7000 rpm pada suhu $4^{0} \mathrm{C}$ selama 15 menit. Endapan yang terbentuk disebut koloidal kitin. Prosedur pembuatan koloidal kitin dapat digambarkan seperti pada Gambar 4. 

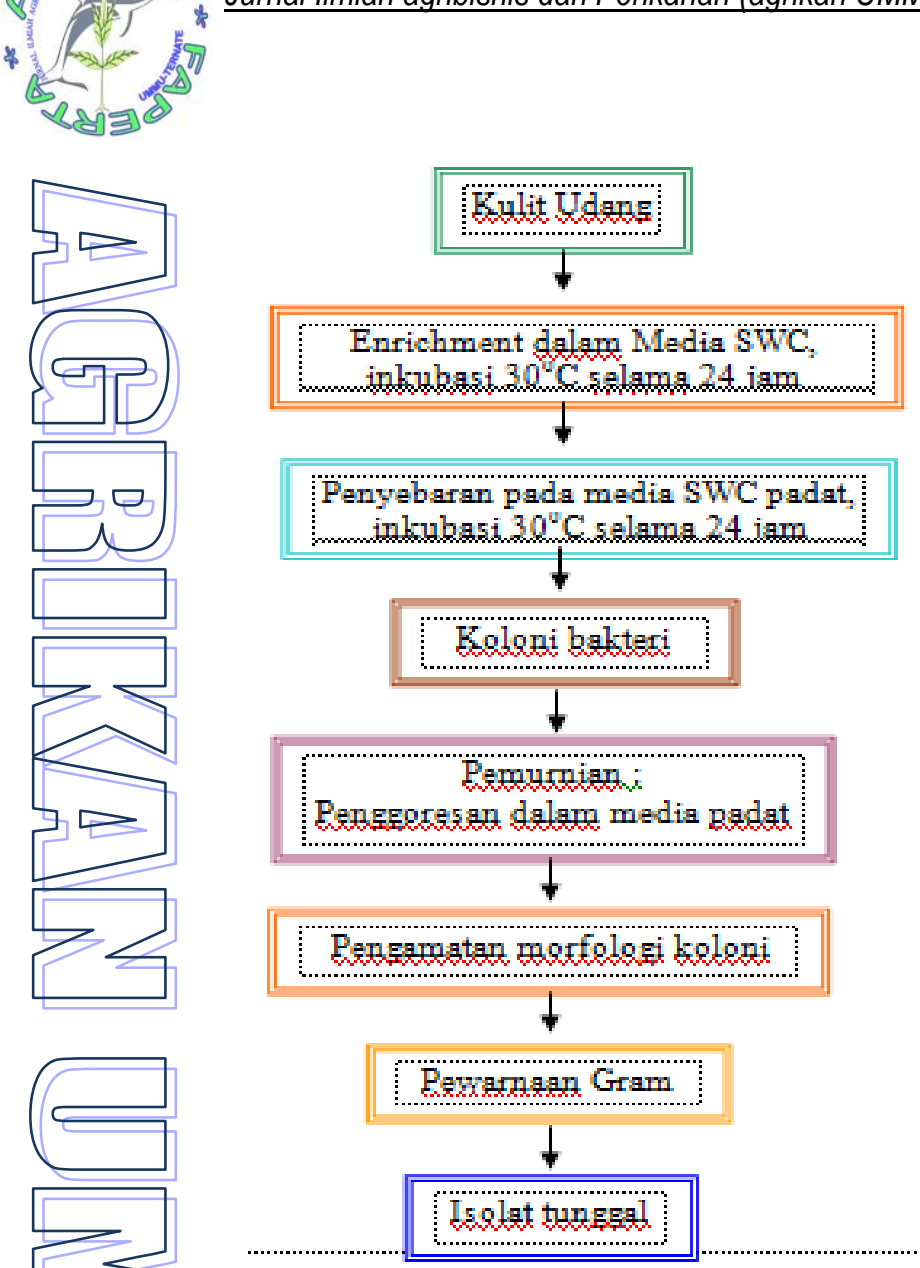

\section{Gambar 3. Isolasi Bakteri pada Kulit Udang}

\section{HASIL DAN PEMBAHASAN}

\subsection{Pengujian Aktivitas Kitonase (Metode Schales)}

Aktivitas enzim ditentukan berdasarkan jumlah glukosamin yang dibebaskan selama hidrolisis substrat kitosan. Satu unit aktivitas enzim didefenisikan sebagai jumlah enzim yang dibutuhkan untuk menghasilkan $1 \mu \mathrm{mol}$ residu glukosamine per menit setelah diikubasi dengan larutan kitosan. Pengujian aktivitas kitonase dilakukan dengan membuat campuran sampel yang terdiri dari $100 \mu \mathrm{mol}$ substrat larutan kitosan, $100 \mu \mathrm{l}$ enzim dan $100 \mu \mathrm{l}$ bufer $\mathrm{pH} 6$. Sementara itu, di tempat terpisah dibuat campuran kontrol yang terdiri dari $100 \mu$ substrat larutan kitosan dan $100 \mu \mathrm{l}$ bufer $\mathrm{pH}$ 6. Sampel dan kontrol diinaktivasi dengan cara dimasukkan ke dalam penangas air bersuhu $100^{\circ} \mathrm{C}$ selama 30 menit.

Tahap selanjutnya adalah pewarnaan terhadap sampel dan kontrol. Pewarnaan sampel dilakukan dengan mencampur $200 \mu \mathrm{l}$ sampel yang telah diinkubasi dengan $800 \mu \mathrm{l}$ dan $1000 \mu \mathrm{l}$ pewarna Schales. Pada tempat terpisah, larutan

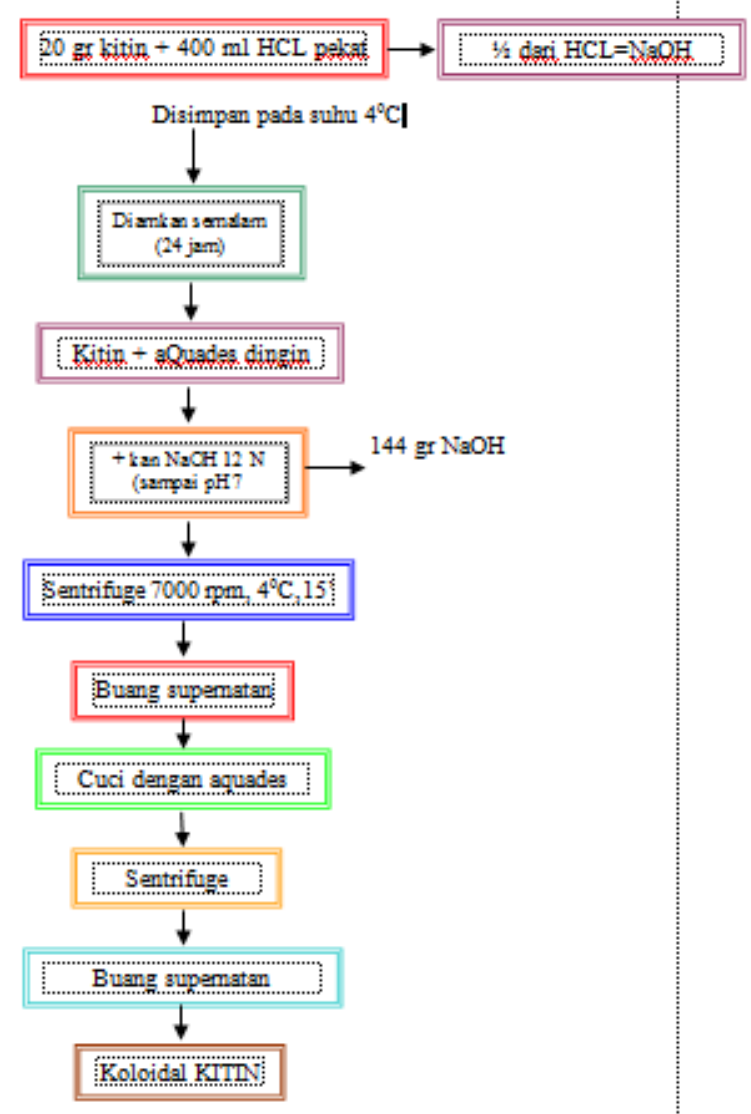

\section{Gambar 4. Prosedur Pembuatan Koloid Kitin}

kontrol di ambil sebanyak $137 \mu 1$ kemudian dicampurkan dengan $67 \mu$ enzim, $800 \mu$ aquades dan $100 \mu 1$ pewarna Schales. Sampel dan kontrol selanjutnya dipanaskan di dalam penangas air bersuhu $100^{\circ} \mathrm{C}$ selama 15 menit. Setelah pemanasan, sampel dan kontrol disentrifugasi dengan kecepatan $8000 \mathrm{rpm}$ pada suhu $4^{0} \mathrm{C}$ selama 10 menit. Sentrifugasi bertujuan untuk memisahkan larutan dengan sisa larutan kitosan. Larutan yang terbentuk dari proses sentrifugasi di ukur nilai absorbansinya pada panjang gelombang $420 \mathrm{~nm}$.

Dari analisis mikrobiologi yang terlihat bahwa dari penyimapan 0 hari sampai hari ke- 7 menunjukkan trend yang sangat berbeda hal ini seiring dengan pertumbuhan bakteri yang terus berkembang dari fase lag 0 hari, fase log pada hari ke-2 dan terus mengalami pertumbuhan pada hari ke- 4 atau fase stasioner dan terus menurun pada hari ke- 6 atau decline fase atau fase istirahat, dimana fase ini bakteri tidak lagi tumbuh tetapi mengalami fase istirahat atau fase kematian. 

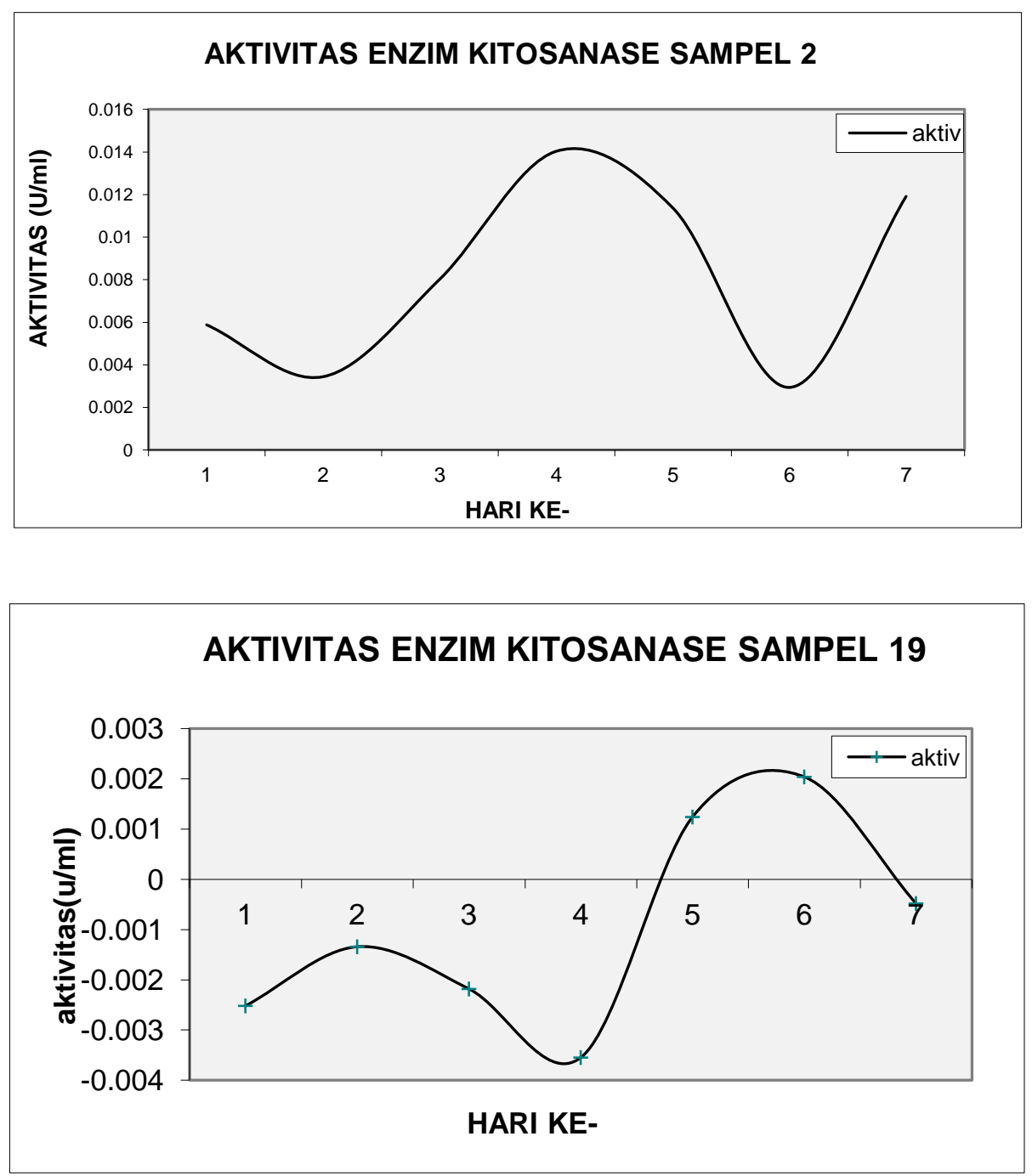

Gambar 5. Aktivitas Enzim

\subsection{Pengukuran Protein (Metode Bradford)}

Analisa ini diawali dengan pembuatan larutan Bradford dan larutan standar BSA. Larutan Bradford dibuat dengan cara sebagai berikut : Sebanyak $100 \mathrm{mg}$ coomassie brilliant blue G-250 dilarutkan dalam $50 \mathrm{ml}$ etanol $95 \%$. Setelah itu $100 \mathrm{ml}$ asam fosfat $85 \%(\mathrm{w} / \mathrm{v})$ ditambahkan. Terakhir larutan diencerkan dengan akuades sampai $1 \mathrm{~L}$. Larutan standar segera dibuat dengan menggunakan protein BSA. Sebanyak $100 \mathrm{mg}$ BSA ditimbang dan ditambahkan $25 \mathrm{ml}$ akuades. Larutan dikocok pelan-pelan, setelah larut diencerkan sampai 50 ml. Konsentrasi akhir larutan stock untuk standar ini adalah $2 \mathrm{mg} / \mathrm{ml}$. Kemudian sederetan larutan standar dengan menggunakan larutan stock di atas.

Setelah semua pereaksi siap, langkah selanjutnya adalah memipet masing-masing larutan dalam tiap tabung sebanyak $0,1 \mathrm{ml}$ dan dimasukkan ke dalam tabung reaksi yang lain yang bersih dan steril. Untuk metode makroessay, sebanyak $5 \mathrm{ml}$ pereaksi Bradford ditamahkan ke dalam masing-masing tabung reaksi, sedangkan untuk mikroessay pereaksi Bradford yang ditambahkan $1 \mathrm{ml}$. Blanko dibuat dengan cara mencampurkan $0,1 \mathrm{ml}$ dan direaksikan dengan $5 \mathrm{ml}$ (makroessay) atai $1 \mathrm{ml}$ (mikroessay) pereaksi Bradford. Setelah sekitar 5 menit, masing-masing campuran reaksi di ukur absorbansinya pada $\lambda=595 \mathrm{~nm}$. Dari sini akan dapat dibuat kurva standar.

Untuk analisis mikrobiologi pada protein terlihat bahwa aktivitas enzim kitosinase pada sampel konsentrasi BSA sampai hari ke-7 menunjukkan trand yang sangat fluktuatif mulai dari hari pertama sampai hari ke-7 menunjukkan trand yang sangat naik hal ini disebabkan karena nutrisi yang terssedia pada media tersebut terus berkembang seiring dengan makan banyaknya nutrisi yang tersedia. 


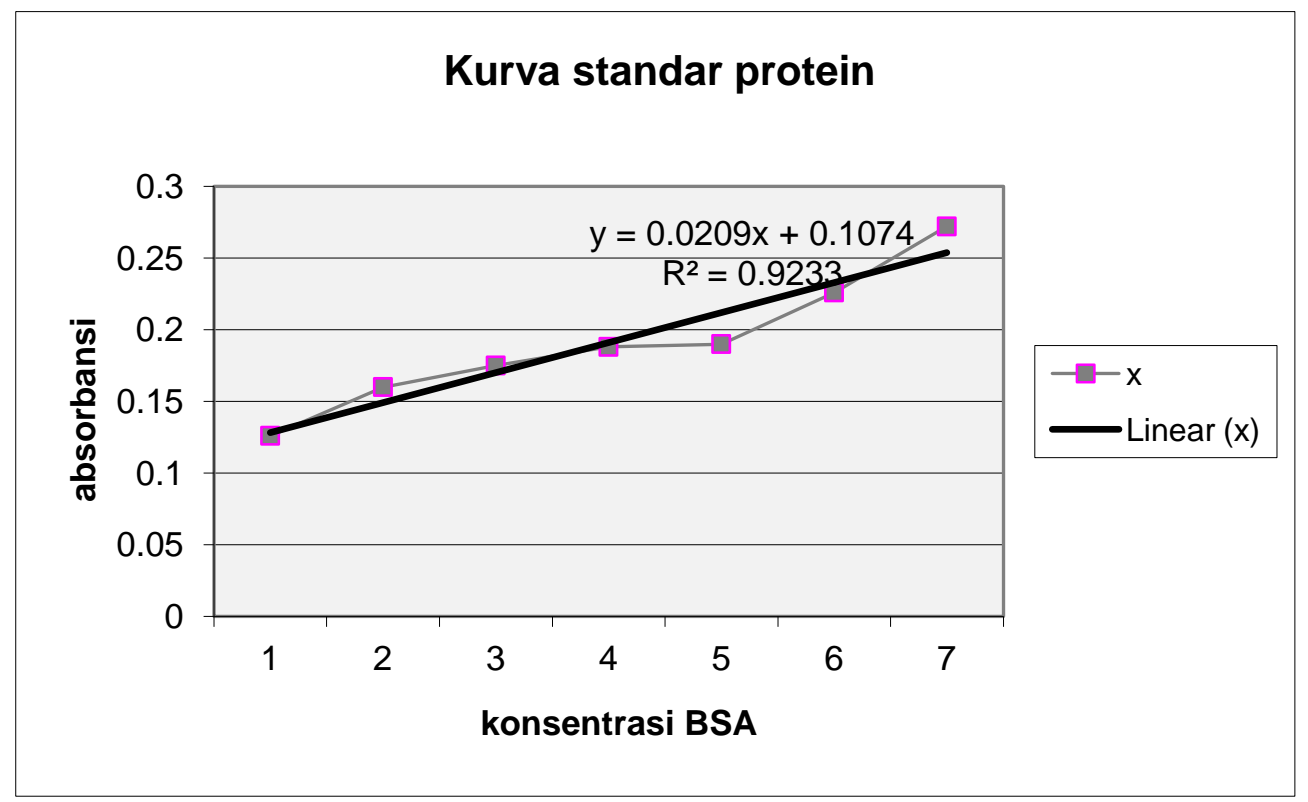

Gambar 6. Kurva Standar Protein

\section{PENUTUP}

\subsection{KESIMPULAN}

1. Kitosan merupakan limbah dari bagian-bagian tubuh udang yang tidak dimanfaatkan dan dibuang pada proses pengolahan yang terdiri dari, kepala, jengger atau genjer, kulit, ekor atau kotoran yang dibuang namun memiliki banyak manfaat untuk kehidupan manusia yang patut dipelajari lebih dalam.

2. Hasil analisis pada enzim kitosinasi trand yang paling tinggi adalah pada hari ke- 4 dan menurun pada hari ke-6, sedangkan aktivitas enzim kitosinase pada sampel yang ke-19 naik pada hari ke-6 dan turun pada hari ke-7 dan untuk konsentrasi bsa terus meningkat dari hari ke-1 hingga hari ke-7.

\subsection{SARAN}

Diharapkan penelitian-penelitian tentang enzim terus dikaji di masa-masa yang akan datang bukan saja enzim pada kulit udang tetapi masih banyak lagi enzim-enzim lain yang belum dimanfaatkan padahal memiliki karakteristik dan manfaat yang cukup besar pula untuk kehidupan manusia terutama dalam bidang-bidang ilmu pengetahuan dan teknologi.

\section{DAFTAR PUSTAKA}

Anonim. 2004.www.dkp.go.id/limbah_udang

Anonim. 2004.www.bps.go.id/produksi_udang_Indonesia

Anonim. 2006. www.bps.go.id/produksi_udang_Indonesia

Bastaman, S. 1989. Studies on degradation and extraction of chitin and chitosan from parwn shells. The Queen's University of Belfast. Belfast.

Cho K. R. 1982. Chitosan as a biomaterial: Biotechnology in the marine sciences. Massachussetts. Institute of Technology: Boston

Gooday G.W. 1994. The Ecology of Chitin Degradation. Vol 11. Advances in micronial Ecology.

Hadie, W. dan J. Supriatna. 1984. Pengembangan Udang Galah dalam Hatcery dan Budidaya. Kanisius. Yogyakarta.

Hall. G.M and De Silva, S., Lactic acid fermentation of scampi (Penaeus monodon) waste for chitin recovery, in Advances in Chitin and Chitosan, (eds. Brine, C.J., Sandford, P.A., and Zikakis, J.P), Elsevier Applied Science, London, 1992, pp. 633-668.

Hadiwiyoto. 1983. Hasil-Hasil Olahan (Susu, Ikan, Daging, Telur). Liberty, Yogyakarta.

Knorr, D. 1984. Use in Chitinous Polymer in the food. Journal of Food Technology. $38: 36$

Muzzareli R.A.A. Joles P.P. 1997.Chitin and Chitinase. Biochemisty of Chitinase. Bikhauser Verlag; Switzerland. 
Neely, M. C. H dan William. 1969. Chitin and Its Derivates in Industrial. Gum Kelco Company California.

Protan Laboratorium. 1987. Caton Polymer for Recovery Valuable by Products from Processing waste Burgess.

Suhartatik, S. 1991. Studi Pendahuluan Pengalengan Udang Windu (Penaeus Monodon) dalam Medium Air Garam dengan Perbedaan Waktu Suhu Sterilisasi. Jurusan Pengolahan Hasil Perikanan Fakultas Perikanan. Institut Pertanian Bogor. Bogor.

Toro, V. dan K. A. Soegiarto.1979. Biologi Udang: Sistematik, Morfologi, Daur Hidup, Habitat dan makanan. Dalam : Udang: Biologi, Potensi, Budidaya, Produksi, dan Udang Sebagai Bahan Makanan di Indonesia. Lembaga Oceanologi Nasional LIPI, Jakarta.

Zeitsev, V., I. et al., Fishing Curing and Processing. Mir Publisher, Moscow. 